\title{
PENERAPAN MODEL PEMBELAJARAN STUDENTS TEAM ACHIEVEMENT DIVISION (STAD) DALAM MENINGKATKAN HASIL BELAJAR AGAMA HINDU
}

\author{
Oleh \\ Ida Bagus Gede Suyadnya \\ Kementerian Agama Kabupaten Jembrana \\ suyadnya.smp4negara@gmail.com
}

Diterima 06 Januari 2017, direvisi 10 Mei 2017, diterbitkan 31 Agustus 2017

\begin{abstract}
The purpose of this research is to know the application of "Cooperative Type" learning model STAD (Student Team Achievement Division) in improving the result of learning Hindu Religion students. This research includes classroom action research (PTK) with cyclustic design In this research used research subjects 13 students, taken from the students of class VII A who have not met the criteria of mastery learning.The target of research is the result of learning Hindu Religion students in SMP Negeri 4 Negara.After the data collected, then analyzed with quantitative descriptive analysis. Results of data analysis showed an increase of average The results of Hinduism learning obtained on the pre cycle of student learning outcomes only reached 69.09 and in the first cycle student learning outcomes increased 77.39.And in Cycle II student learning outcomes rose to 83.48 Or from pre-cycle to cycle I increased by $12,01 \%$, from pre cycle to cycle II equal to $20,83 \%$, and cycle I to si Second cluster of $7.87 \%$. Based on the results of this data analysis, it can be concluded that the implementation of Cooperative Type STAD learning model can improve the learning result of Hindu religion students in SMP Negeri 4 Negara, Jembrana District.
\end{abstract}

Keywords: Cooperative learning, STAD type, and learning outcomes

\section{PENDAHULUAN}

Peran mata pelajaran Agama Hindu adalah untuk pengembangan mental spiritual ,intelektual, sosial dan emosional siswa. Di samping mengetahui peran mata pelajaran
Agama Hindu sebagai seorang guru juga diharapkan mampu menerapkan beberapa model pembelajarandalam meningkatkan hasil belajar siswa sesuai tuntutan peraturan pemerintah(Permen No. 41 tahun 2007 tentang 
Standar Proses, yang dirubah menjadi Permen Dikbud No.65 tahun 2013 tentang Standar proses Pendidikan Dasar dan Menengah.

Bila berbicara masalah hasil belajar siswa, khususnya siswa Sekolah Menengah Pertama (SMP), segera terlintas dalam pikiran kita bahwa hasil belajar yang dimaksudkan adalah nilai yang diperoleh siswa pada suatu bidang studi tertentu setelah mengalami proses belajar dalam jangka waktu tertentu. Ketika menelusuri hasil belajar siswa SMP dalam bidang studi Pendidikan agama Hindu, salah satu bahan yang tepat untuk ditelusuri adalah perolehan hasil belajar agama Hindudi suatu kelas pada setiap Rencana Pelaksanaan Pembelajaran (RPP).

Berdasarkan data yang ada, hasil belajar agama Hindu siswa SMP Negeri 4 Negara tergolong rendah walaupun berbagai upaya telah dilakukan pemerintah untuk meningkatkan hasil belajar dalam mata pelajaran Agama HIndu, seperti melalui penyempurnaan kurikulum, peningkatan fasilitas dan media pembelajaran, mengadakan penataran bagi guru-guru agama Hindu, mensuplai buku-buku yang relevan, program Academic Staff Deployment (ASD), dan memberi kesempatan bagi guru untuk menempuh pendidikan pada jenjang yang lebih tinggi. Semua usaha ini belum memberikan hasil yang diharapkan.Hal ini terbukti dari perolehan hasil belajar agama Hindu siswa kelas VIIA.Berpatokan pada ketuntasan belajar pada mata pelajaran agama Hindu, siswa kelas VIIA pada semester genap tahun ajaran 2015/2016 memperoleh hasil sebagai berikut. Sebanyak 10 siswa memperoleh skor agama Hindu memenuhi Ketuntasan belajar dan 13 siswa memperoleh skor agama Hindu tidak memenuhi ketuntasan belajar.

Rendahnya hasil belajar yang diperoleh siswa SMP yang tercermin melalui hasil belajar dalam setiap RPP merupakan tantangan yang sangat serius bagi Lembaga Pendidikan, khususnya bagi pendidik (guru) yang langsung terlibat dalam pembelajaran agama Hindu.Rendahnya nilai UASAgama Hindu yang diperoleh siswa ini perlu mendapat kajian yang serius bagi kalangan praktisi pendidikan.Hal ini bertujuan untuk mengetahui faktor-faktor penyebabnya serta mencari alternatif-alternatif solusinya.

Masalah rendahnya nilai UAS Agama Hindu yang diperoleh siswa merupakan tanggungjawab kita bersama untuk mengupayakan supaya nilai UASagama Hindu siswa SMP di masa yang akan datang dapat ditingkatkan. Bilahasil belajar siswa SMP dalam bidang studi Pendidikan Agama Hindu rendah, dapat diestimasi bagaimana kemampuan sumberdaya manusia di bidang mental spiritual dan IPTEK. Kemungkinan di masa yang akan datang, sumberdaya manusia yang ada tidak bisa bersaing di tingkat nasional maupun internasional dalam percaturan dunia IPTEK dalam rangka menghadapi segala tuntutan di era globalisasi.

Sehubungan dengan penggunaan model pembelajaran, seorang guru harus jeli (prigel) di dalam memilih model pembelajaran yang akan diterapkan di kelas. Dalam dunia pendidikan terdapat banyak model pembelajaran, namun tidak semua model pembelajaran ampuh untuk mencapai tujuan pembelajaran pada setiap kompetensi dasar. Suatu model pembelajaran hanya ampuh untuk suatu kompetensi dasar tertentu, namun di lain pihak kurang ampuh untuk mencapai tujuan pembelajaran pada kompetensi dasar yang lainnya. Hal ini sesuai dengan pernyataan yang dikemukakan oleh Soetomo (1993: 144) bahwasannya model yang tepat untuk salah satu tujuan pengajaran (pembelajaran), atau bahan pengajaran belum tentu tepat untuk tujuan dan bahan pengajaran yang berbeda.Pemilihan model pembelajaran merupakan spesifik pada proses pembelajaran tertentu.

Menurut Puger (2004: 14), untuk meningkatkan hasil belajar siswa diperlukan strategi dan metode pembelajaran yang dapat mengembangkan penanaman konsep, penalaran, dan memotivasi kegiatan belajar 
siswa. Salah satu model pembelajaran yang dapat menumbuhkan pemahaman, penalaran, dan memotivasi kegiatan belajar siswa adalah dengan menggunakan modelpembelajaran kooperatif (cooperative learning). Dengan menggunakan model pembelajaran kooperatif, maka pengungkapan konsep-konsep dalam suatu bidang studi dapat diwujudkan melalui cara-cara yang rasional, komunikatif, edukatif, dan kekeluargaan.

"Belajar Kooperatif merupakan suatu struktur organisasional yang mana satu kelompok siswa mengejar tujuan akademik melalui usaha bersama dalam kelopok kecil menarik kekuatan masing-masing yang lainnya dan bantuan masing-masing yang lainnya dalam melengkapi tugas. Model pembelajaran Kooperatif ini menganjurkan hubungan yang saling menunjang, ketrampilan komunikasi yang baik, dan kemampuan berpikir pada tingkatan yang lebih tinggi”. ( Hilke, 1998:14 )

Kejadian yang sering terjadi di lapangan selama proses pembelajaran yang dilakukan selama ini yang menyebabkan rendahnya hasil belajar disebabkan oleh faktor luar seperti kesibukan guru, keadaan rumah tangga, dan lingkungan. Sedangkan faktor dari dalam guru itu sendiri seperti kemauan menyiapkan bahan yang lebih baik, kemauan guru itu sendiri untuk menerapkan model-model pembelajaran. Selain itu guru juga kurang mampu untuk dapat mengembangkan keterampilan mengajar yang dapat menarik perhatian siswa dan merangsang siswa untuk belajar. Keterampilan-keterampilan ini berhubung dengan kemampuan guru untuk menguasai dasar-dasar pengetahuan yang berhubungan dengan persiapan dan pelaksanaan proses pembelajaran yang akan memberikan dukungan terhadap cara berpikir siswa yang kreatif dan imajinatif. Hal inilah yang menunjukkan profesionalisme guru (Wardani dan Julaeha )

Lebih lanjut dikatakan, belajar Cooperatif Type STAD yang dikembangkan pertama kali oleh Elliot Aronson sebetulnya menggunakan spesialisasi tugas.Masing-masing siswa mempunyai sebuah tugas yang berkontribusi untuk team/kelompok. Masing-masing siswa bekerja secara individu untuk mencari jawaban terhadap quis / pertanyaan yang diperoleh dan dapat bertanggungjawab untuk menyampaikan informasi kepada yang lainnya dalam kelompok dan juga menguasai informasi anggota kelompok lainnya.

Pembelajaran kooperatif tipe STAD merupakan pembelajaran yang kegiatannya lebih terpusat pada siswa, siswa dibagi dalam kelompok-kelompok kecil yang terdiri atas 45 orang.Dalam kelompok kemampuan siswa harus heterogen. Setiap siswa dalam kelompok akan mendapat tugas yang berbeda, dan masing-masing siswa akan menjawab quis / pertanyaan yang didapat, kemudian hasilnya akan dikonfirmasikan padateam /kelompok, bila ada permasalahan barulah anggota kelompok yang lain membantunya. Di sini, guru hanya berperan sebagai fasilitator dan moderator dalam mengambil simpulan pada saat diskusi berlangsung. Dengan mempelajari sendiri, mendiskusikan, menemukan, dan menghayati sendiri konsep-konsep penting yang terkandung dalam materi yang dibahas, diharapkan dapat meningkatkan pemahaman siswa dan menumbuhkan rasa percaya diri, serta keterampilan sosial mereka, di samping peningkatan hasil belajar siswa itu sendiri . Hal ini merupakan implikasi dari pendapat Slavin (1995: 12), yang menyatakan model pembelajaran kooperatif memiliki pengaruh yang positif dalam memperbaiki hubungan antar-kelompok dan rasa percaya diri siswa, sehingga tumbuh motivasi dalam diri siswa untuk mengulang kegiatan tersebut. Metode pembelajaran ini sangat sesuai jika diterapkan pada kelas yang memiliki kemampuan heterogen, karena siswa yang kemampuannya kurang akan dibantu oleh siswa yang memiliki kemampuan baik pada saat kerja kelompok.

Pada hakikatnya, model pembelajaran kooperatif tipe STAD memberikan kesempatan 
pada siswa untuk berdiskusi, bekerja mandiri , berpikir kritis,dan pengenalan team .Akhirnya setiap siswa mengerjakan quis / pertanyaan yang diperoleh. Model pembelajaran kooperatif tipe STAD ( Student Team Achievement Divition ) ini diharapkan dapat meningkatkan hasil belajar agama Hindu siswa kelas VIIA pada setiap siklus.

Berpijak atas kenyataan-kenyataan di atas, dapat dirumuskan masalah sebagai berikut. Apakah penerapan model pembelajaran kooperatif tipe STAD dapat meningkatkan hasil belajar Agama Hindu di SMP Negei 4 Negara siswa kelas VII Asemester genap tahun pembelajaran 2015/2016?

Model pembelajaran kooperatif memiliki pengaruh yang positif dalam memperbaiki hubungan antar-kelompok dan rasa percaya diri siswa, sehingga tumbuh motivasi dalam diri siswa untuk mengulang kegiatan tersebut. Model pembelajaran ini sangat sesuai jika diterapkan pada kelas yang memiliki kemampuan heterogen, karena siswa yang kemampuannya kurang akan dibantu oleh siswa yang memiliki kemampuan baik pada saat kerja kelompok (Slavin, 1995).

Hasil penelitian dapat memberikan efek utama bahwa model pembelajaran yang diterapkan dalam proses pembelajaran berpengaruh secara signifikan terhadap hasil belajar siswa. Temuan ini membuktikan bahwa guru sudah tepat memilih modelpembelajaran dalam melaksanakan proses pembelajaran karena pemilihan model pembelajaran merupakan hal yang tidak boleh dikesampingkan. Hal ini sejalan pula dengan temuan-temuan peneliti lain seperti yang dilakukan oleh Inten (2004) dan Puger (2004) yang pada dasarnya menyatakan bahwa model pembelajaran yang diterapkan berpengaruh terhadap hasil belajar siswa.

Mata pelajaran Agama Hindu menitikberatkan kajiannya pada aspek Kognitif, Afektif dan Psikomotor sebagai pedoman atas kemampuan siswa baik pikiran, prilaku maupun keterampilan yang dimiliki. Untuk semua bantuan terhadap hal ini, model pembelajaran Students Team Achievement Division (STAD) menempati tempat yang penting karena dapat mengaktifkan siswa secara maksimal. Dari nilai yang diperoleh siswa, seluruh siswa mendapat nilai di atas Ketuntasan belajar, dan tidak ada siswa memperoleh nilai rendah. Dari perolehan nilai ini sudah dapat diyakini bahwa hasil belajar siswa dapat ditingkatkan dengan penggunaan model pembelajran Students Team Achievement Division(STAD).

\section{PEMBAHASAN}

\subsection{Hasil Penelitian}

Pada prasiklus digunakan metode pembelajaran konvensional untuk menyajikan materi ajar pengertian dan pembagian Sapta Timira.Setelah dilakukan pengukuran ternyata diperoleh hasil sebagai berikut. Sebanyak 10 siswa $(43 \%)$ siswa memperoleh skor memenuhi ketuntasan belajar dan 13 siswa (57\%) siswa memperoleh skor di bawah ketuntasan belajar, dengan rerata hasil belajar agama Hindu sebesar 69,09

Pada siklus I digunakan metode pembelajaran kooperatif tipe STAD untuk mengomunikasikan materi ajar contoh prilaku sapta timira dan Kitab suci yang memuat ajaran sapta timira. Hasil pengukuran menyatakan sebanyak 15 siswa (65\%) siswa memperoleh skor memenuhi ketuntasan belajar dan 8 siswa (35\%) siswa memperoleh skor tidak memenuhi ketuntasan belajar, dengan rerata hasil belajar agama Hindu sebesar 77,39. Oleh karena indikator keberhasilan belum terpenuhi, maka penelitian tindakan kelas ini dilanjutkan pada siklus II.

Pada siklus II digunakan metode pembelajaran kooperatif tipe STAD untuk mengomunikasikan materi ajar dampak pengaruh ajaran sapta timira dan cara mengatasinya. Hasil pengukuran menyatakan sebanyak 23 siswa (100\%) siswa memperoleh 
skor memenuhi ketuntasan belajar, dengan rerata hasil belajar agama Hindu sebesar 83,48. Oleh karena indikator keberhasilan sudah terpenuhi, maka penelitian tindakan kelas ini tidak dilanjutkan pada siklus berikutnya.

Hipotesis tindakan yang diuji kebenarannya berbunyi "Penerapan model pembelajaran kooperatif tipe STAD dapat meningkatkan hasil belajar Pendidikan Agama Hindu siswa". Hipotesis tindakan ini selanjutnya diuji melalui analisis data dengan analisis deskriptif kuantitatif.

Perbandingan rerata hasil belajar Pendidikan Agama Hindu siswa dari prasiklus ke siklus I menunjukkan peningkatan skor sebesar $12,01 \%(69,09-77,39)$, prasiklus ke siklus II menunjukkan peningkatan skor sebesar 20,83\% (69,09-83,48), dan siklus I ke siklus II menunjukkan peningkatan skor sebesar $7,87 \%(77,39-83,48)$. Dari ketiga perbandingan rerata skor hasil belajar agama Hindu yang dilakukan ternyata ketiga perbandingan tersebut menunjukkan peningkatan, yakni sebesar 12,01\%, 20,83\%, dan $7,87 \%$. Oleh karena ketiga perbandingan rerata skor hasil belajar agama Hindu menunjukkan peningkatan, maka hipotesis tindakan yang diajukan ternyata benar.

Hasil analisis data menunjukkan penerapan model pembelajaran kooperatif tipe STAD dapat meningkatkan hasil belajar agama Hindudi SMP Negeri 4 Negara.

Hal ini disebabkan oleh bidang studi agama Hindu merupakan bidang studi yang unik, karena untuk memahami konsep secara holistik harus mulai dulu memahami konsep dari yang konkret menuju ke abstrak.Bilamana seorang guru bisa mengemas pembelajaran dengan menggunakan model pembelajaran yang menuntut pemahaman konsep secara konkret dan abstrak dapat menghindarkan siswa dari peristiwa miskonsepsi. Hal ini sejalan dengan pernyataan Tirta (1994: 5), yang mengungkapkan pembelajaran dengan bantuan media yang diperoleh akan lebih bermakna bila dibandingkan hanya mengomunikasikan materi ajar secara simbul verbal.

Salah satu model pembelajaran yang bisa diterapkan dalam rangka memahami konsep secara konkret dan abstrak adalah model pembelajaran kooperatif tipe STAD. Pada saat siswa yang memperoleh quis/pertanyaan yang harus dijawab sendiri, didahului dengan mengamati media slide / tayangan film keagamaan. Dengan mengamati tayangan slide, seorang siswa dapat secara langsung mengetahui objek dari suatu konsep. Pengamatan tayangan slide pada kelompok / team merupakan dasar dari pemahaman konsep secara konkret. Selanjutnya, siswa diwajibkan membaca literature atau buku paket yang dirujuk oleh guru agama hindu sebelum menjawab quis / pertanyaan yang menjadi tanggungjawab masing-masing anggota kelompok, bila ada kesulitan baru didiskusikan pada anggota kelompok yang lain. Pemahaman konsep terdefinisi pada buku-buku agama hindu merupakan dasar dari pemahaman konsep secara abstrak. Pemahaman konsep-konsep agama hindu secara holistik ini dapat meningkatkan hasil belajar agama Hindu siswa di SMP Negeri 4 Negara.

Hasil penyelesaian tugas oleh masingmasing anggota kelompok selanjutnya disampaikan pada team/kelompok kerja. Hal ini bertujuan agar informasi yang merupakan jawaban dari quis / pertanyaan yang diperolehdapat diketahui oleh anggota kelompok yang lain. Dalam hal ini, seorang siswa hanya mengerjakan satu quis / pertanyaan, dengan menyampaikan informasi akhirnya memperoleh informasi jawaban dari semua quis / pertayaan yang dibebankan.Dengan penekanan bahwa pada saat siswa berdiskusi pada kelompok / team harus semua berkolaborasi dan saat menyampaikan hasil tugas pada kelompok harus percaya diri. Hal dapat mengkibatkan hasil belajar agama hindudi SMP Negeri 4 Negara menjadi meningkat. 
Tes hasil belajar yang diperoleh telah menemukan efek utama bahwa penggunaan model pembelajaran tertentu akan berpengaruh terhadap hasil belajar siswa yang dalam hal ini adalah model pembelajaran Students Team Achievement Division (STAD). Hal ini sesuai dengan hasil meta analisis model pembelajaran yang dilakukan oleh Soedomo, 1990 (dalam Puger, 2004) yang menyatakan bahwa model pembelajaran yang diterapkan oleh seorang guru berpengaruh terhadap hasil belajarnya.

Seperti telah diketahui bersama bahwasannya mata pelajaran Agama Hindu menitikberatkan pembelajaran pada aspek kognitif, Afektif dan Psikomotor sebagai pedoman prilaku kehidupan sehari-hari siswa. Maka penggunaan model pembelajaran ini dapat membantu siswa untuk berkreasi, bertindak aktif, bertukar pikiran, mengeluarkan pendapat, bertanya, berdiskusi, berargumentasi, bertukar informasi dan memecahkan masalah yang ada bersama dengan anggota kelompok diskusinya. Hal inilah yang membuat siswa berpikir lebih tajam, lebih kreatif dan kritis sehingga mampu untuk memecahkan masalahmasalah yang kompleks dan efek selanjutnya adalah para siswa akan dapat memahami dan meresapi mata pelajaran Agama Hindu lebih jauh.

Model pembelajaran kooperatif memiliki pengaruh yang positif dalam memperbaiki hubungan antar-kelompok dan rasa percaya diri siswa, sehingga tumbuh motivasi dalam diri siswa untuk mengulang kegiatan tersebut. Model pembelajaran ini sangat sesuai jika diterapkan pada kelas yang memiliki kemampuan heterogen, karena siswa yang kemampuannya kurang akan dibantu oleh siswa yang memiliki kemampuan baik pada saat kerja kelompok (Slavin, 1995).

Hasil penelitian ini ternyata telah memberi efek utama bahwa model yang diterapkan dalam proses pembelajaran berpengaruh secara signifikan terhadap hasil belajar siswa. Temuan ini membuktikan bahwa guru sudah tepat memilih model pembelajaran dalam melaksanakan proses pembelajaran karena pemilihan model pembelajaran merupakan hal yang tidak boleh dikesampingkan. Hal ini sejalan pula dengan temuan-temuan peneliti lain seperti yang dilakukan oleh Inten (2004) dan Puger (2004) yang pada dasarnya menyatakan bahwa model pembelajaran yang diterapkan berpengaruh terhadap hasil belajar siswa.

Peningkatan prestasi dan hasil belajar siswa melalui penerapan model pembelajaran STAD ( Student Team Acheivement Divition ) juga dapat dilihat dari hasil penelitian yang dilakukan oleh Ni Luh Rasmini ( 2010 ) dan Widiasa ( 2012 ).

Hasil belajar menunjuk pada perubahan struktur pengetahuan individu sebagai hasil dari situasi belajar.Hasil belajar beraneka ragam besarnya, baik yang menyangkut belajar fakta sederhana maupun keterampilan-keterampilan tehknis yang bersifat kompleks. Hasil belajar juga berbeda dalam kawasan isi, yang meliputi hasil belajar efektif dan keterampilanketerampilan sosial, keterampilan-keterampilan motorik dan pengetahuan prosedural ( Santyasa, 2005).

Melihat perbandingan nilai awal, nilai siklus I dan nilai siklus II, terjadi kenaikan yang signifikan, yaitu dari rerata nilai awal adalah 69,09. naik di siklus I menjadi 77,39 dan di siklus II naik menjadi 83,48 Kenaikan ini tidak bisa dipandang sebelah mata karena kenaikan nilai ini adalah dari upaya-upaya yang maksimal yang dilaksanakan peneliti demi peningkatan mutu pendidikan dan kemajuan pendidikan khususnya di SMP Negeri 4 Negara , kecamatan Negara, Kabupaten Jembrana, Propinsi Bali .

\section{SIMPULAN}

Berpijak atas pembahasan tersebut di atas dapat disimpulkan bahwa penerapan model pembelajaran STAD dapat meningkatkan hasil belajar Pendidikan Agama Hindu, hal ini ditunjang oleh perbandingan rerata skor dari 
prasiklus, siklus I, dan siklus II, yaitu pencapaian kenaikan hasil belajar siswa sebagai berikut.

a. Dari data pra siklus ada 13 siswa mendapat nilai di bawah 75 , pada siklus I menurun menjadi 8 siswa dan siklus II seluruh siswa mendapat nilai di atas 75 .

b. Dari reratapra siklus 69,09 naik menjadi 77,39 pada siklus I naik sebesar $12,01 \%$, dari pra siklus ke siklus II naik menjadi 83,48 atau sebesar 20,83\% dan dari siklus I ke siklus dua naik lagi7, $87 \%$.

c. Dari data pra siklus siswa yang tuntas hanya 10 orang sedangkan pada siklus I menjadi lebih banyak yaitu 15 siswa tuntas dan pada siklus II menjadi semua siswa yaitu 23 siswa yang tuntas.

\section{DAFTAR PUSTAKA}

Badan Standar Nasional Pendidikan. 2007.

Peraturan Menteri Pendidikan Nasional Republik Indonesia Nomor 41 Tahun 2007. Jakarta: BSNP.

Hilke, Eileen Veronica. 1998. Fastback Cooperative Learning. New York: McGraw-Hill, Inc.

Inten, I Gede. 2004. Pengaruh Model Pembelajaran dan Pengetahuan Awal
Siswa Terhadap Prestasi Belajar PKn dan Sejarah pada Siswa Kelas II di SMU Laboratorium IKIP Negeri Singaraja. Tesis. Program Pascasarjana IKIP Negeri Singaraja.

Puger, I Gusti Ngurah. 2004. Belajar Kooperatif. Diktat Perkuliahan Mahasiswa Unipas.

Santyasa. 2005. Belajar dan Pembelajaran. Singaraja : IKIP Singaraja.

Slavin, Robert E. 1995.Cooperative Learning : Theory, Research, and Practice. Boston: Allyn and Bacon.

Soetomo, M. 2001. Landasan Pendidikan. Malang: Penyelenggaraan Pendidikan Pascasarjana Proyek Peningkatan Perguruan Tinggi.

Wardani, I. G. A. K Siti Julaeha. Modul IDIK 4307. Pemantapan Kemampuan Mengajar. Jakarta: Universitas Terbuka.

Widiasa,I Made. 2012. Peningkatan Prestasi Belajar Siswa melalui Model Pembelajaran Student Team Acheivement Divition ( STAD) di Kelas XI Semester IV SMA Negeri 1 Kerambitan Tahun pembelajaran 2011/ 2012. Penelitian Tindakan Kelas . Tabanan .Disdikporabud. 